\title{
Concatenating Effects Due to Transformation of Morogoro Road to BRT Corridor: A Case of Dar es Salaam, Tanzania
}

\author{
Ombeni Swai \\ School of Architecture and Design, Ardhi University, Dar es Salaam, Tanzania \\ Email: swaiarcht@gmail.com
}

Received 23 March 2016; accepted 27 June 2016; published 30 June 2016

Copyright (C) 2016 by author and Scientific Research Publishing Inc.

This work is licensed under the Creative Commons Attribution International License (CC BY). http://creativecommons.org/licenses/by/4.0/

c) (i) Open Access

\begin{abstract}
This study was set to elucidate the concatenating effects caused by the transformation of Morogoro Road to accommodate Bus Rapid Transport (BRT) system. The study was conducted from 2013 to 2014 covering demolition, excavation and construction process of the new BRT system. Both field survey and literature reviews were applied, where the real case was taken at a strip between Manzese and Magomeni. Data collected in a form of in-depth interview, observations and questionnaires were analyzed by the use of Statistical Package for Social Studies (SPSS Version 16). About 200 respondents whose physical structures were affected by the demolition process were involved in the data collection. The study revealed that physical demolition directly affected about $70 \%$ of the respondents. The effects extended into financial implications, which, then trickled down into social, psychological and spatialaspects. According to the findings from the respondents, a number of various socioeconomic activities such as groceries, clothing shops, saw mill and building material shops were affected and as a result, the effect led into retrenchment of the supporting staff. One of the major findings in this study is that the government and consultants need to consider a wide scenario of what might be the effects of physical demolition at the social and family level so that they may prepare a program to take care of those who are affected when paving way for development, and that the compensation should be extended to the tertiary level to take care of social and psychological effects.
\end{abstract}

\section{Keywords}

BRT, Livelihood, Community, Tanzania, Transportation

\section{Introduction}

For more than ten years, Dar es Salaam city has been experiencing high urbanization and transport challenges 
which needed a holistic approach to give a relief to road users particularly bearing in mind that urbanization in Dar es Salaam has gone hand in hand with a demand for other corresponding services such as transportation systems, water supply, power supply, properly addressed land use strategies and employment to mention a few. As an intervention measure, the government of Tanzania under the finance of the World Bank came up with an idea of introducing rapid transport system named as Dar Rapid Transport (DART) as a means of reducing transport hassles particularly in the city of Dar es Salaam and its outskirts.

Transportation challenges for Dar es Salaam City have been of a high demanding as compared to other services. Nevertheless, efforts to curb the situation had not been seriously thought to arrest the situation until when the World Bank through the Dar Rapid Transport (Dart) project came as a redeeming entity. Due to long term sufferings from traffic jams, high expenditure on fuels, delays, air pollution, etc., the introduction of the project was warmly welcomed and wasreceived as a once and for all solution to ease long hours of traffic jams to roads entering the city. However, to residents living and conducting socio-economic activities along Morogoro Road the project is ill-received and perceived particularly when it interferes with their means of bread earnings (socioeconomic activities).

Outcries of Dar es Salaam residents have aired that since the Morogoro Road Corridor becomes the backbone route for the Dart, it has been troublesome as residents along this carriageway can no longer access their business premises due to a random overhaul of the arterial roads, which has demolished most of the then existing shops and offices along the road, created rain water flow towards the existing buildings and hampered nearly all socio-economic activities which are taking place along the corridor. For example, in some areas of the new road, the level of the road is higher than building levels thus causing rain water to flow into buildings. Not only that but also, the new design of the road has cut off all the manoeuvrings from the main route to service roads which are used to serve the existing shops, offices and residential buildings along the corridor. The inaccessibility impacts are not only to business owners but it cuts across to customers, passers-by, landlords, school kids, and all other users respectively causing a multiplying effect to residents.

Dart project is divided into six phases, where the first phase is the corridor runs from Ferry to Kimara and Kawawa Roadin which, the residents along the corridor are the first to experience the resentment of demolition of their properties to pave way for Dart infrastructure. Pertaining to major impacts, famous Morogoro Road has become the backbone route for the Dart, which has totally transformed it and turned it into a nightmare as residents can no longer access their business premises while random overhaul of the arterial road has been blamed for causing lengthy traffic jams in many parts of the commercial capital (Finnigwa, 2013).

Impacts of phase one of the Dart project can be categorized into three stages namely demolition, construction, and usage of the new roads. In all of these stages of the project, various impacts to business owners, residents, users (drivers, pedestrians, motorists, cyclists, cart and pushers) vary significantly depending on the stage of the project. For example, during demolition, business owners and other property owners along the corridor were the major victims due to loss of properties along the road reserve. Those who were compensated to give more room for road expansion also experienced several inconveniences to move away and look for another piece of land to establish their new settlements. As a result, some have changed their status from being landlords to tenants due to in-affordability to build new houses. Moreover, some have sought to buy land pockets from within the nearby settlements for fear of losing social contacts thus resulting into further compaction of the built environment.

Construction stage of this corridor is another major impact to nearly all users from individual to the national level. Construction of the corridor has taken a long time to the extent that many users and the national economy have been affected to a large extent. Traffic jam for example has raised concern to many users... "Traffic piles up on a lengthy section of Bibi Titi Road due to the ongoing construction of Morogoro Road that forms the backbone of the Dar es Salaam Rapid Transport (DRT), a project that some residents now see as serious pain in the flesh as many have had their premises blocked". (Mambo, 2013). The resident continues to complain that a short distance (Kimara to city center) which used to take at least half an hour before construction it takes about three hours "Saturday' survey, it sometimes takes over three hours to commute from Kimara to the city centre, which is a mere 16 kilometres away. Largely, as a result of the ongoing construction of the road some residents think is too sluggish and somewhat leisurely. "This is a lifeline not only for Dar es Salaam residents but also for the whole country such that digging it up without well laid out detours and diversions that allow traffic to flow smoothly is disastrous," said HalidyAmri, a resident of KimaraMbezi. The same resident continues narrating that "I wondered why the contractor, was allowed to tear up the busy road while construction seems to be going on at a rather leisurely pace. This resident was of the opinion that works should have been carried on day and 
night to allow life to go back to normal in a reasonably short time. Views from this observerechoes the feelings of many city residents whose initial excitement at the launch of the project has now turned into dissatisfaction and even outright anger over the way an otherwise important project was being implemented. Businesses that have had their access literally blocked or cut off include fuel filling stations, shops and hotels (said another resident).

Another resident lamented that "three months have gone by now and we don't even know if we are going to resume operations here or not," said Ilyas Abdallah, Manager of the Akiba junction Total Tanzania Limited filling station. Mr Abdallah said that access to the filling station has been blocked for over three months and all 12 attendants have been sent on unpaid leave. The same resident continues arguing that "Because this road will only be used by rapid transport buses, we don't even know whether cars will be allowed to refill here." The Manager of the Kisutu Oilcom Tanzania Limited filling station, Fuadi Karama, also expressed similar concerns. "This contractor is not concerned with time. They have taken over three months so far on this segment of the road," said Mr Karama.

The above businessmen urged the Tanzania Roads Agency (TANROADS) to compel the contractor to work day and night in order to hasten implementation of the important project that will no doubt add to the beauty of the city of over four million people and bring hitherto unknown comfort, reliability and order in the now highly chaotic commuter services.

Other complaints raise similar concerns "thecontractor has taken more than three months to dig up a one kilometre stretch from the junction of Bibi Titi Road and Samora Avenue. "We have lost more than 60 per cent of our clients because they cannot access the hotel since the road is closed," said the Assistant Manager of Rainbow Hotel, Mr Baiju Sukumaran. He also expressed fears over the future of their Mega Investment since Morogoro Road will be closed to private cars used by most of their clients. These complaints show that a number of space users in the city are not well informed of the project; neither doesit understand the fate of their business and other socio-economic activities when the road is completed.

Bus Rapid Transport systems have being operational in other countries and cities such as Curitiba, Colombia, Bogota, Brisbane, Jakarta, Stockholm, Cape Town, Ottawa, etc. to mention a few. The BRT system has been reported to solve many urban transport challenges and that it is considered to be basically a low cost investment in infrastructure and well integrated in operational improvement.

Studies have shown that one of the many advantages of Bus Rapid Transit is to integrate land use and transportation systems in which compact, pedestrian-oriented land use development are mutually supportive and that the clustering of development has additional benefit of conserving land and promoting the vitality of neighborhoods and urban commercial centers (Lai, 2007). Moreover, the BRT is believed to be most effective when integrated within a broader planning framework encompassing land use policies, zoning regulations, economic and community development (Ibid). In addition to that, BRT goes hand in hand with improved facilities and amenities whereby the operational and travel time benefits resulting from the separation of buses from generalpurpose traffic can be augmented with improved amenities such as bus shelters and stations which end up improving urban outlook.

Learning from the case of South Africa, BRT is considered to be the first case study in Africa where several advantages such as economic growth, poverty alleviation, restructuring the city, sustainable development and good governance have been experienced (Allen, 2005). However, in the process of implementing the project, several challenges were experienced including a resistance of change from those who were benefitting from the present system-the informal minibus owners and drivers. This resistance does not mean that residents do not like to get good and modern transport system but they want that their means of bread earning be put in a better system or be integrated in the new system before it is introduced. Precisely, the outcry of the residents is that a better and thorough understanding of the existing condition be fully considered before removing it out of place. This is similar to what happened in Dar es Salaam where, although the residents did not resist for the new DART project, they have complained significantly regarding the demolition of their premises and the fate of their activities along the road is not known. It has been commented that African cities are in a desperate need of decent public transport services yet their introduction is often hampered by a strong and influential informal sector (ibid), meaning that the informal sector which provides services in many African cities does not welcome the formal system to be introduced because of the fear of formalization, nevertheless, new projects in cities of African need to consider an integral system of both formal and informal operation in order to solve urban challenges amicably. 
In the case of Curitiba Brazil, the introduction of BRT was governed by the Master Planindicating priority areas where the city growth should be directed to thus designating a corridor in a linear form spurred by zoning and land use policies in which mass transitwould replace the car as the primary means of transport within the city, and the high density development along the corridors thus producinga high volume of transit ridership. Likewise, the Morogoro Road corridor has many opportunities for commercial activities which will replace the demolished ones.

Learning from the cases from South Africa and Curitiba on how the BRT transformed the corridor along the transport routes in terms of spurring the economic opportunities, it is most likely that the corridor along the Morogoro road will economically boost the new transport corridor. Never the less, the challenges to displace people and compensating them need to be properly addressed. It has been estimated that 60 per cent of development-induced displacement every year-about 6 million people is a result of urban infrastructure and transportation project. The study continues to unveil that urban infrastructure and transportation projects that cause displacement include slum clearance and upgrading; the establishment of industrial and commercial estates; the building and upgrading of sewerage systems, schools, hospitals, ports, etc.; and the construction of communication and transportation networks, including those connecting different urban centres (Cernea, 1996).

As it can be understood from the above studies that, vast literature existing pertinent to the introduction of BRT systems in cities focuses on the positive aspects of the BRT projects rather than the understanding of the implementation process and challenges to the residents. Since DART is planned to be implemented in phases, the study from Morogoro Road Corridor (phase one) is meant to understand the process and the respective challenges to people conducting socioeconomic activities along the corridor. It is also intended that the findings from this study may be applied or used to improve other similar challenges in the next phases and hence minimize or avoid further outcry from the residents along those respective corridors.

This study intends to explore the concatenating impacts onpublic (all users) particularly those who conduct socio-economic livelihood activities along the first phase-corridor. The study focuses along the corridor from Manzese to Magomeni Road Junction (Figure 1). This corridor is selected due to a concentration of socio-economic activities which existed before the demolition stage. It is a place concentrated by various small and medium shops, stores and offices to represent other activities of similar nature taking place along the entire corridor. Since the study concentrateson the immediately effects and their corresponding multiple impacts, it focuses onthose activities which were immediate facing the road. The objective is to understand the impacts, raise awareness and prepare the coping strategies to other ongoing phases of DART in Dar es Salaam.

\section{Materials and Methods}

\subsection{Materials}

Research methodology is a way to systematically solve a research issue, which may be understood as a science of studying how research is done scientifically, systematically and logically to arriving into a conclusion. Based on the nature of the study, which aims at understanding the impacts to socio-economic activities and to the livelihoods of the activity-owners, this study applies a case method where in particular the case of Morogoro Road is selected. Case study is used in many situations to contribute to knowledge of individuals, group, and organizational, social, political and related phenomena (Yin, 2002). This study has drawn case studies of Bus Rapid Transport from other cities around the world in order to find out how challenges related to implementing such a system in Tanzania can be dealt with. Yin continues to narrate that the case study has been a common research strategy in psychology, sociology, and political science social works business, and community planning (Gilgun, 1994) (Ghauri \& Gronhaug, 2002). It is further clarified that the central tendency among all types of case studies is that it tries to illuminate a decision or a set of decisions: why they were taken, how they were implemented (process) and with what results (impacts) (Schramm, 1971).

The case of a road section along Morogoro Road is studied in order to find out the following:

1) Whether there were people whose physical structures were demolished to pave way for new construction;

2) Types of activities which were affected during the demolition;

3) The physical situation before and after the demolition;

4) The extent of impacts economically, socially, and psychologically. Explicitly, the study is structured to understand the extent of the impacts of physical demolition to the people living along Morogorogo Roadin order to create a better knowledge of the process of road expansion and devise means to deal with such in other 


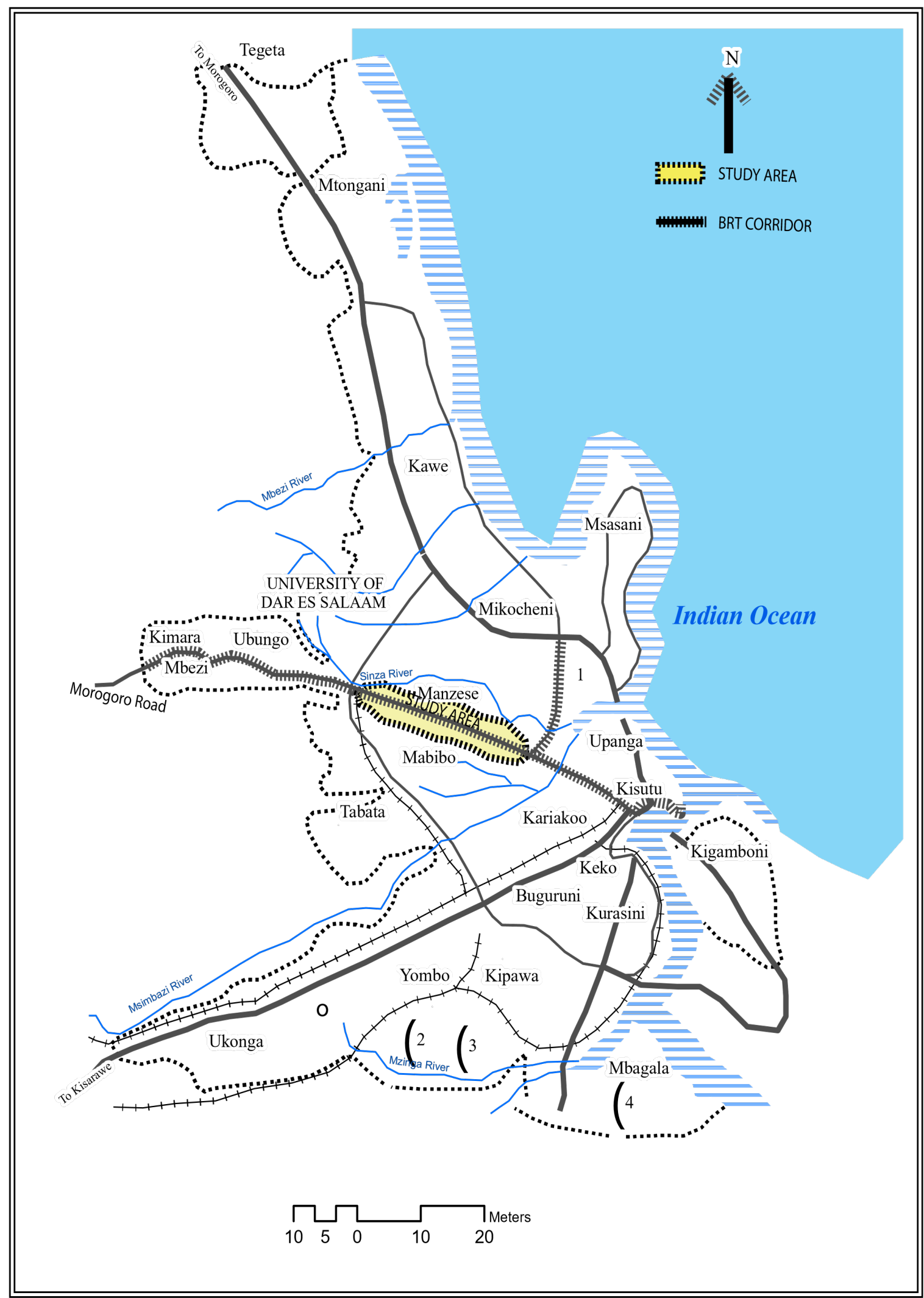

SOI IRCF. Adnnted from Kvesci and Frited hv Author 2015

Figure 1. Map of dar es salaam indicating phase 1 Dart Corridor and the study area-author, 2015. 
development-related projects along the roads and also to advise the government on the policy considerations for the victims of demolitions.

Questionnaire: A sample of two hundred respondents (200) was conducted to have the residents understanding of the level of impacts caused by the demolition and the new construction that has to a large extent hampered the previous flexibility and access to the spaces of socio-economic activities. Both structured and open endedquestionnaires were conducted by the author being assisted by four students of architecture (fourth-year) from January to September 2013 (nine months). Questionnaires were analyzed by the use of Statistical Package for Social Sciences (SPSS Version 16).

Literature: Review was extensively referenced from existing Bus Rapid Transportstudies as well as those cities where such projects were introduced. The existing literature was useful from the fact that it helped the author to have a better understanding of the concept of BRT, its challenges, and the process of implementation. Moreover, the existing body of knowledge helped the author to understand the gap that exists and which needs to be discussed for a better comprehension of the subject matter.

Analysis: Based on the nature and objectives of this study, data analysis was mainly done by using Statistical Package for Social Sciences (SPSS version 16), while those related to space were graphically analyzed.

\subsection{Conceptual Framework}

Analysis of the socio-economic impacts to residents living and conducting activities along Morogoro Dart Corridor examines the immediate effects (primary impacts), the secondary as well as tertiary-level effects. The intertwining between the immediate effects (primary) and the associated effects in secondary and tertiary levels is what the study refers to as concatenating (multiplying) effects. The concatenating framework was applied as a basis for preparing data collection i.e. the questionnaires were prepared to understand both the immediate impact

demolition) and the multiplying impacts after the demolition such as loss of working space, loss of economic activity, loss of customers, failure to repay loan, failure to pay rent, failure to pay children 'school fees, failure to sustain the family, and bankruptcy., to mention just a few (Figure 2). The conceptual framework also considers

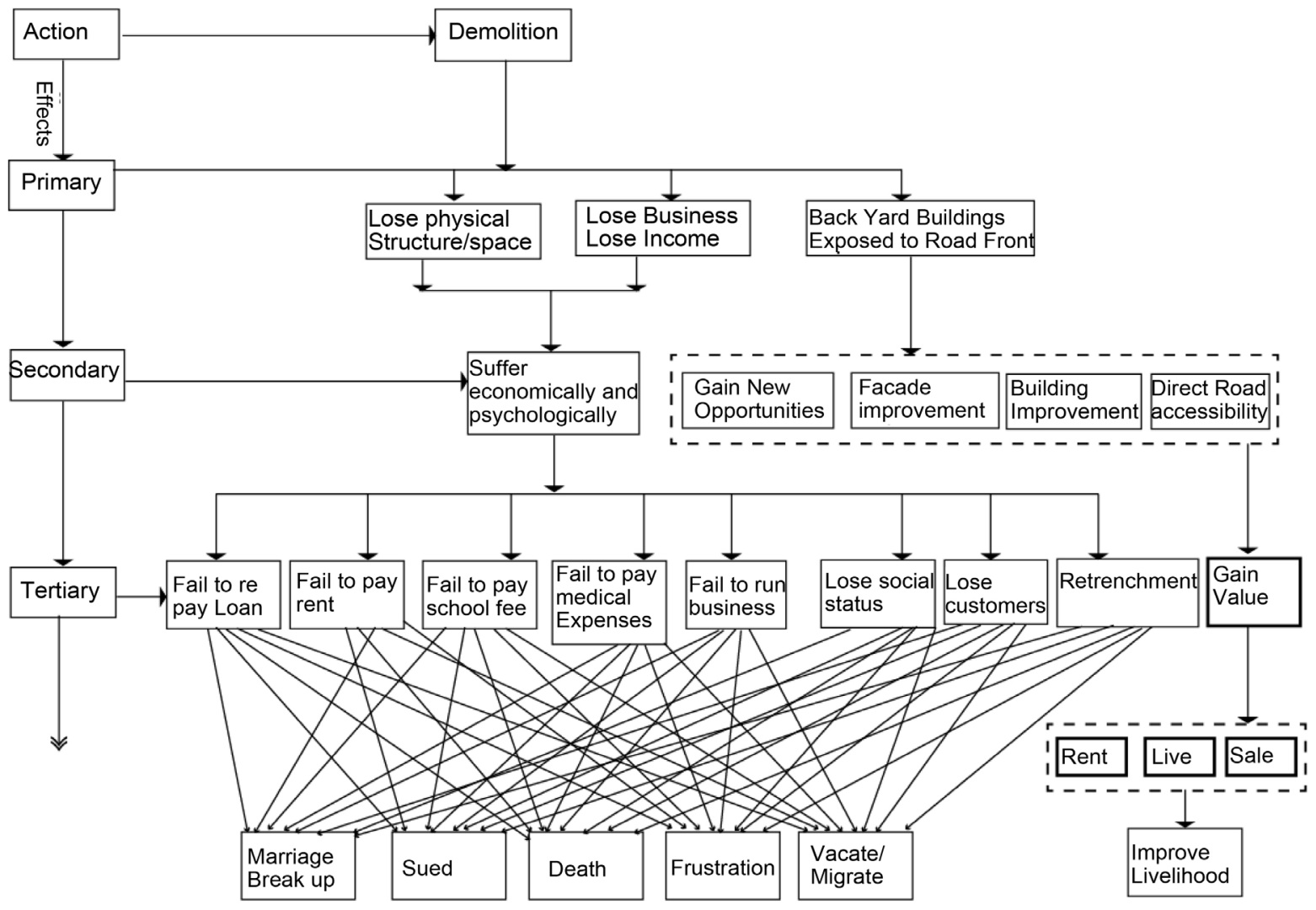

Figure 2. Framework to study concatenating effects due to demolition-author, 2014. 
positive aspects of demolition such as value increase in space near the road which give more chances to rent properties, good living spaces, and high market value in case of sale of properties. Although physical demolition may have some positive aspects, some studies have shown that the negative impacts have various consequences including loss of identity, feeling marginalized and displaced, loss of land, loss of families and role models, and being disadvantaged in their new places (Bennett \& McDowell, 2012). The same study continues to high light that consequences extend far beyond mere economic loss, impacting mental health and wellbeing of the displaced population (McDowell, 1996).

\section{Results and Discussion}

\subsection{Demolition of Physical Structures and Socio-Economic Impacts}

Transformation of Morogoro Road fromits original use as a normal two-lane carriage way to a six-lane Rapid Bus Transport route has involved an expansion of the road which included demolition of some of the building structures along the corridor. The process to demolish the structures was preceded by compensation to those who had built based on formal process, i.e., with building permit and other statutory documents to occupy the structure along the road. Not all were compensated depending on the formality of the building structure, nevertheless, even for those who were compensated they were not satisfied with the amount of money since the demolition process rendered them to lose social groups (groups of people dealing with certain type of socio-economic activity), neighbourhood among the people, financial assurance of getting little money on daily basis, etc.

Victims of resettlement do express dissatisfaction not necessarily due to the act of relocation, but due to the outcome of resettlement as asserted that "place, in whatever guise, is like space and time, a social construct" (Harvey, 1996: p. 261). Harvey continues to iterate that place is indeed socially, politically and culturally constructed because the ways in which people experience place and the meaning people ascribe to it, come out of a socioeconomic, political and cultural milieu, which is in turn dominated by socioeconomic, political and cultural values (Ibid).

During the field work, one of the respondents said "although I was paid money to move out, but I feel that I have lost my life" meaning that since he has been working in the same area for more than four years, his life is already attached to the people and the surroundings (space-attachment). Similarly, to this study, others have shown that losing a place where one conducts a day-to-day activity causes impacts into other areas of life such as socioeconomic, political and cultural contexts within which the individual's bond with place and his/her experiences are embedded (Heidegger, 1958; Wen, Hodgetts, \& Ho, 2010).

Others have shown that the individual's feeling about a place which he/she inhabits is moulded by social ideologies as well as the individual's actions and relationship to those social norms (Ahrentzen, 1992). It goes on affirming that important places are those in which events occur and that mark people's particular experiences in new or unique ways (Li \& Chong, 2012). Those experiences, either positive or negative, are considered as growth experiences because they are events that help move people's life journey forward. Furthermore, it is conceded that, places serve as markers in the individual's journey and become significant because of experience (Manzo, 2005).

Subjective experiences within particular places shape, and are shaped by, people's relationships to each other, society, and particular settings (Satg'e, 2002; Cunningham, 2004; Comey, 2004). In the study area, one victim raised her voice that "I was born here, my children go to school because of this small space I used to occupy before demolition, so I don't feel to move, I will fail to support my family"-Mwanahamisi, 2013. Residents who had lived and conducted activities along the Morogoro Road had strong connections to the context, something which made them suffer emotionally during demolition.

Considering about resettlement for development projects, some institutions such as the Inter-American Development Bank have developed guidelines to consider the welfare of the people who undergo resettlement. One of the guidelines requires that the affected population can achieve an equivalent or improved standard of living within a reasonable time, and they should be given access to land, natural resources, housing and infrastructure of level at least equivalent to that which they previously enjoyed, allowing them to recover or improve their income levels within reasonable period. Moreover, those who undergo resettlement should be provided with an acceptable level of services, including portable water, drainage, and sanitation and community infrastructure regardless of their previous conditions (OP-710, 1988).

Citing from the above body of literature, in relation to the study area it was found that out of 192, about 
sixty-nine percent (69\%) expressed that they had a direct impact, while $29.2 \%$ responded that they had no impact from the ongoing road transformation (Table 1). The percentage of those who were affected by the road transformation represents more than sixty-percent $(60 \%)$ of the total number of the respondents implying that the impact of demolition was extensive and worth considerations to minimize it in future.

\subsection{Taxonomies of Socio-Economic Activities Affected by Demolition}

One of the reasons to select the study area is due to its richness in varieties of economic activities which business people carry out on daily basis. It was then established that about $31 \%$ of socio-economic activities in the study area deal with clothing, which was followed by building materials $20.8 \%$, and groceries (20.3\%) (Table 2). These were the most mentioned among the respondents although others such as offices, residential units, etc appeared in a small percentage. The richness due to varieties of activities can be one of the factors attracting people to shop at this area as emphasized in the responsive environment that variety is one of the seven qualities of the built environment (Bentley et al., 1985).

\subsection{The Situation before and after Demolition-Impact to Physical Accessibility}

In the new road boundaries, buildings which were hidden in the rear side of the road were exposed to the road front thus giving them a gain value in terms of having direct accessibility from the road, improved facades to suit the new road image, some were re built, while others gave new commercial possibilities (Figure 3). As a result of the improvements, the buildings gained value whether for rent, live or sale. Any of these possibilities is an opportunity to improve livelihood and living conditions. This implies that the demolition of buildings along the road has a dis advantages on one side to those who lose their properties but also it has some good opportunities for improving living condition as well as giving a better street image (streetscape).

In the process of demolition, many of the building accessibilities were blocked either temporarily or permanently to date due to the nature of the new road system. As a result, many shops are no longer accessible by trucks as complained by respondents. "Imagine, before I used to bring my goods up to the door by my car. These days, the car can not access the shop, even customers hesistate to buy because they can not carry heavy stuff because they will incur double costs to hire a cart". Another respondent said "I have to park my car away from my shop because there is no way I can access my shop anymore, how then can I bring in my customers?" he lamented. Likewise, a customer supported the above complaints by saying that "if you want to access these shops by car you have to go a long distance before you get an access point. The new road is good but not for the business along it. He concluded. According to the study, it shows that before demolition, only 30 shops were not accessed by trucks to bring in goods, while after the new road system about 125 shops are not accessible (Table 3).

Table 1. Activity area was affected (demolished/blocked). Source: author 2014.

\begin{tabular}{ccccc}
\hline Response & Respondents $(\mathbf{N}=\mathbf{2 0 0})$ & Percent & Valid Percent & Cumulative percent \\
\hline Valid yes & 134 & 69.8 & 69.8 & 69.8 \\
No & 56 & 29.2 & 29.2 & 99.0 \\
I don't know & 2 & 1.0 & 1.0 & 100.0 \\
Total & 192 & 100.0 & 100.0 & \\
\hline
\end{tabular}

Table 2. Typologies of socio-economic activities in the study area: author 2014.

\begin{tabular}{|c|c|c|c|c|}
\hline Typology & $\begin{array}{l}\text { Respondents } \\
\qquad(\mathrm{N}=200)\end{array}$ & Percent & Valid percent & Cumulative percent \\
\hline Grocery & 39 & 20.3 & 20.3 & 20.3 \\
\hline Sawmill & 27 & 14.1 & 14.1 & 34.4 \\
\hline Building materials & 40 & 20.8 & 20.8 & 55.2 \\
\hline Residential & 26 & 13.5 & 13.5 & 68.8 \\
\hline Clothes & 60 & 31.2 & 31.2 & 100.0 \\
\hline Total & 192 & 100.0 & 100.0 & \\
\hline
\end{tabular}


Table 3. Truck accessibility to deliver commodities to shops before and after demolition-author, 2014.

\begin{tabular}{ccccc}
\hline Response & Respondents $(\mathbf{N}=\mathbf{2 0 0})$ & Percent & Valid Percent & Cumulative percent \\
\hline Valid cant access & 155 & 80.7 & & \\
Can access & 30 & 15.6 & 82.0 & 82.0 \\
Don't know & 4 & 2.1 & 15.9 & 97.9 \\
Total & 189 & 98.4 & 2.1 & 100.0 \\
Missing system & 3 & 1.6 & 100.0 & \\
Total & 192 & 100.0 & & \\
\hline
\end{tabular}

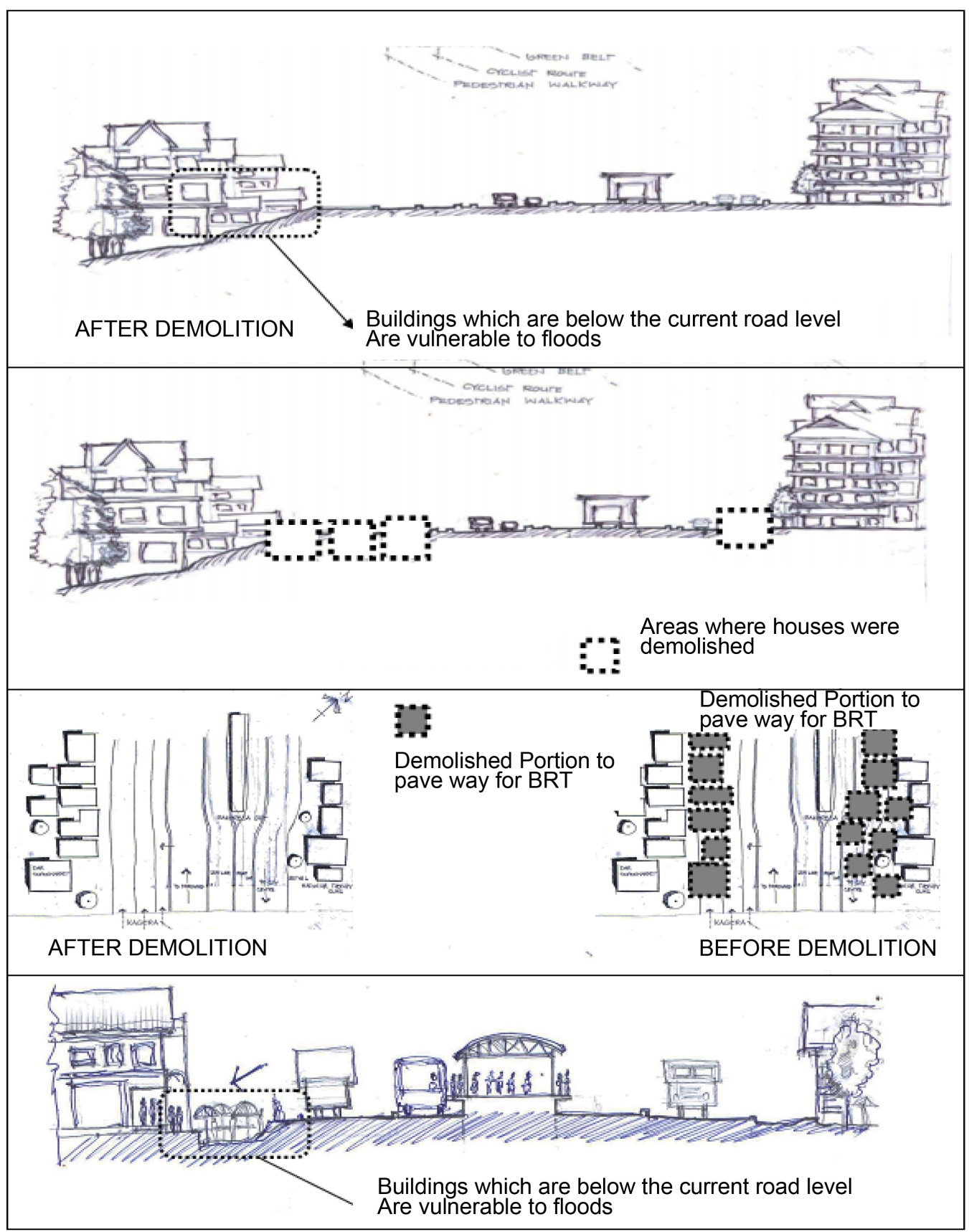

Figure 3. Field sketches demonstrating the situation before and after demolition. Source: author 2014. 
This is a decrease of $76 \%$ inaccessibility. According to the owners of these shops they have to incur extra cost such as hiring carts to bring in goods to the shops. According to owners, this may discourage customers or completely deny them the right of shopping in the area.

\subsection{Economic Impacts to Activity Owners-Drop in Sales and Loss of Customers}

People are always attached to space, and the relationship between space and people can be due to its appearance, quality, location, ownership, contents, and friendship with the space owner or proximity to customers. The relationship implies that any alteration of space by demolition, reduction or increment of its size or quality have various impacts to the users (customers). In the case of the Morogoro Corridor, the relationship between the commercial activity-space and the nature of ownership was assessed. Firstly, it was to establish how long the space owners had being conducting socio-economic activities, which was meant to establish the nature of tenancy whether permanent or temporary. Period of occupancy was divided in short intervals such as 1 - 2 years, 3 - 5 years, 6 - 10 years, 11 - 15 years. It was established that there is a smooth variation in terms of the duration of occupancy as follows; the majority $29 \%$ had been conducting activities for $3-5$ years, followed by those who had occupied the spaces for more than ten years (27\%) Table 4.

Under normal circumstances, owners who had conducted activities in the same area for more than three years had established both commercial relationship with the customers as well as the social relationships with theirneighbors and the surroundings. Consequently, it was found that after the process of demolition of the commercial spaces, the number and confidence from daily customers dropped significantly. Confirming the fall of the number of customers, it was observed that out of 192 respondents, about seventy-nine percent $(79.2 \%)$ responded by saying that they experienced the drop of customers (Figure 4). Only a small percentage 13\% stated that they were not affected, however by comparing those who were affected (79\%) and those who were not affected (13\%), it is obvious to conclude that the majority were affected by losing long term and close customers, which, also led to the drop of sales (Table 5).

From the historical point of view, the study area has been a famous place in terms of both wholesale and retail commercial activities. It is also one of the very famous places (Manzese) along Morogoro Road, where many people to and from the city center drop by for shopping since it is believed that commodities and foodstuffs in this place are cheaper as compared to other areas of the City. It is noticed that besides the fact that Manzese offers cheap food stuff and commodities during the demolition of the road there was a significant drop of the percentages of sales to amongst the respondents as follows; for the majority (48\%) sales dropped between 10\% - 30\%

Table 4. Duration of occupation by tenants before demolition.

\begin{tabular}{ccccc}
\hline Duration of occupancy & Respondents $(\mathbf{N}=\mathbf{2 0 0})$ & Percent & Valid percent & Cumulative percent \\
\hline 1 - 2 years & 45 & 23.4 & 24.2 & 24.2 \\
3 - 5 years & 56 & 29.2 & 30.1 & 54.3 \\
- 10 years & 33 & 17.2 & & \\
$11-15$ years & 52 & 27.1 & & \\
Total & 186 & 96.9 & 17.7 & 72.0 \\
Missing system & 6 & 3.1 & 28.0 & 100.0 \\
Total & 192 & 100.0 & 100.0 & \\
\hline
\end{tabular}

Table 5. Drop in sales due to demolition-author, 2014.

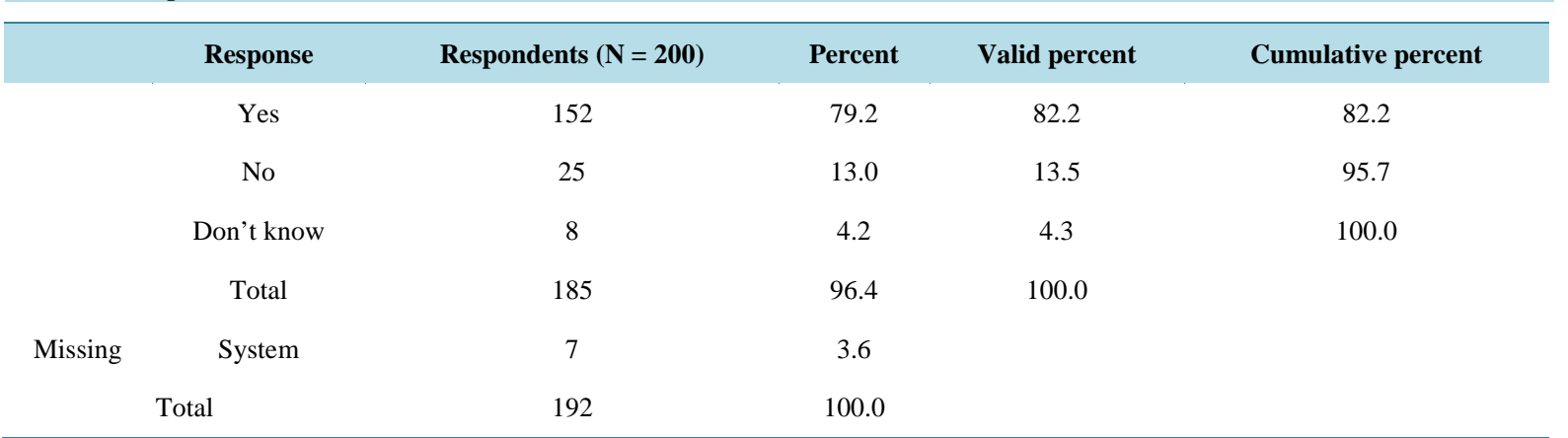




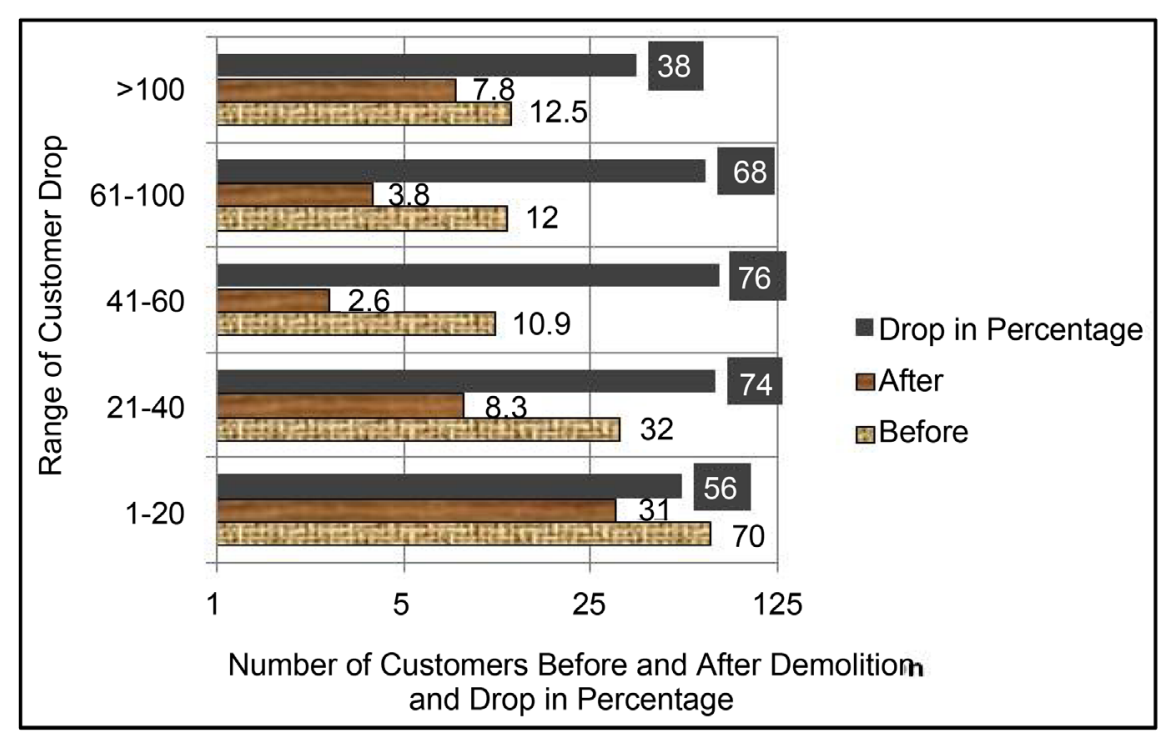

Figure 4. Drop of customers in shops.

of total sales, which was followed by a drop between $40 \%$ - 70\% per day (31\%) of the respondents (Table 6). The drop of more than fifty percent in sales is a significant amount in socio-economic activities. Due to the consequences of reduction of the number of customers per day as well as the profit loss, some business owners opted to retrench the number of workers or lay off all non-related family members in order to minimize expenditures. The study has shown that about $60.9 \%$ of the shop owners had to retrench the workers. This was affirmed by one of the shop owners by saying that "in this shop we used to employ 3 of our relatives, but these days the business has droped, only me and my husband are enough to serve the few customer we have".

Based on the above concerns, it shows that people carrying out socioeconomic activities along the corridor have more concern in relation to how their commercial activities are affacted by the new road system rather than the new outlook of the road.

\subsection{Impacts of Demolition to Service Supply-Utilities}

The process of demolition, excavation and reconstruction was associated with other problems to residents such as disconnection of water supply, electricity and other services as noted from one of the respondents "this project has jut taken away my water and electricity. Every day I experience water and electricity shortage since this project started. Worse enough, I don't know when they will finish it" complained one of the respondents. Statistically, the study shows that demolition and excavation of the road had impacts to people in terms of water supply and electricity since the entire infrastructure was to be removed to pave way for the new road, Table 7.

\subsection{Tertiary Impacts of Demolition}

This section tries to enumerate how the impact of demolition trickled down to individual level (Table 8), family level where, respondents demonstrated how they could not continue with the same type of lifestyle they had before the demolition. The study shows that after the demolition, the aftermath effect could be categorized into four major types; 1) those who could not meet their financial responsibilities such as failing to pay loans, losing trustworthy in business, fail to proceed with business, run bankrupt, etc.; 2) those who could no longer meet social responsibilities such as failing to pay house rent, medical bills and school fees for kids; 3 ) Those who could not fulfil their plans in life such as failing to reach target thus forced to change activities or migrate into another place. The last group is those whose marriages experienced conflicts due to psychological impacts of losing the activity space/structure.

Through cross tabulation, demolition was taken as a cause while the other four impacts were treated as the outcome in each case.

The above analysis shows the trickling down of the effects of demolition in which all types of effects are 
Table 6. Drop in percentage of sales/day.

\begin{tabular}{ccccc}
\hline Drop in percentage & Respondents $(\mathbf{N}=\mathbf{2 0 0})$ & Percent & Valid percent & Cumulative percent \\
\hline $10 \%-30 \%$ & 92 & 47.9 & 48.4 & 48.4 \\
$40 \%-70 \%$ & 59 & 30.7 & 31.1 & 79.5 \\
$80 \%-100 \%$ & 39 & 20.3 & 20.5 & 100.0 \\
Total & 190 & 99.0 & 100.0 & \\
Missing system & 2 & 1.0 & & \\
Total & 192 & 100.0 & \\
\hline
\end{tabular}

Table 7. Whether demolition has caused retrenchments supporting staff.

\begin{tabular}{ccccc}
\hline Response & Respondents $(\mathbf{N}=\mathbf{2 0 0})$ & Percent & Valid percent & Cumulative percent \\
\hline Yes & 117 & 60.9 & 60.9 & 60.9 \\
No & 57 & 29.7 & 29.7 & 90.6 \\
Do not know & 18 & 9.4 & 9.4 & 100.0 \\
Total & 192 & 100.0 & 100.0 & \\
\hline
\end{tabular}

Table 8. Other problems caused by demolition.

\begin{tabular}{|c|c|c|c|c|c|}
\hline Type of Services & & $\begin{array}{c}\text { Respondents } \\
(\mathbf{N}=\mathbf{2 0 0})\end{array}$ & Percent & $\begin{array}{c}\text { Valid } \\
\text { percent }\end{array}$ & Cumulative percent \\
\hline & Water system & 74 & 38.5 & 41.6 & 41.6 \\
\hline & Electrical system & 29 & 15.1 & 16.3 & 57.9 \\
\hline & transport system & 75 & 39.1 & 42.1 & 100.0 \\
\hline \multirow{3}{*}{ Missing } & Total & 178 & 92.7 & 100.0 & \\
\hline & System & 14 & 7.3 & & \\
\hline & & 192 & 100.0 & & \\
\hline
\end{tabular}

itemized. In the case of the impacts of demolition to financial matter, item number 2, 6, 3 and 4 were the highest experienced by the respondents (Table 9). For the case of demolition to social effects, the analysis shows that items 3 and 2 had the highest occurrence meaning that the majority were evicted from the houses they were renting due to failure to pay rent, and also children suffered from failure to pay school fees (Table 10). In terms of the effects of demolition to individuals life plan, it shows the about 153 respondent were not able to reach the target they had set for themselves (Table 11). When respondents were asked to give more details of the meaning of target, it was ranging from buying a plot, opening another shop, building a house, buying a car, expanding business, etc. All in all, the word target was used by the respondents meaning to improve living condition at individual or family level.

For the case of demolition with marriage, the analysis indicates that all respondents experienced some problems in marriage such as fighting, quarrelling, over drinking, etc., where some ended up in breaking up (Table 12). When these four scenarios are closely observed, it can be understood that the first impact which all respondents experienced was to suffer financially, which, triggered to all other three effects (Social responsibility, Life plan, and Marriage issues). This can be graphically expressed by Figure 5 .

\section{Conclusion and Policy Implication}

This study was set to elucidate the process of implementation of BRT project along Morogoro road where, through this process the road was transformed from normal carriageway to accommodate BRT system. The 
Table 9. Cross tabulating demolition to financial impacts demolition effects financial effects cross tabulation.

\begin{tabular}{|c|c|c|c|c|c|c|c|c|c|}
\hline & \multicolumn{8}{|c|}{ Financial effects } & \multirow{2}{*}{ Total } \\
\hline & 1 & 2 & 3 & 4 & 5 & 6 & 7 & 8 & \\
\hline Demolition effects court & 35 & 88 & 81 & 1 & 72 & 88 & 1 & 21 & 387 \\
\hline \% within financial effects & $100.0 \%$ & $100.0 \%$ & $100.0 \%$ & $100.0 \%$ & $100.0 \%$ & $100.0 \%$ & $100.0 \%$ & $100.0 \%$ & $100.0 \%$ \\
\hline Total court & 35 & 88 & 81 & 1 & 72 & 88 & 1 & 21 & 387 \\
\hline$\%$ within financial effects & $100.0 \%$ & $100.0 \%$ & $100.0 \%$ & $100.0 \%$ & $100.0 \%$ & $100.0 \%$ & $100.0 \%$ & $100.0 \%$ & $100.0 \%$ \\
\hline
\end{tabular}

Where numbers (key) stands for: 1-Loss of credibility in business. 2-Fail to pay loan. 3-Fail to proceed with business. 4-Business plan slowed down. 5-Run bankrupt. 6-Fail to acquire new loan. 7-Loss of trustworthy. 8-Sued to failure to pay loan.

Table 10. Cross tabulating demolition to social impacts.

\begin{tabular}{|c|c|c|c|c|}
\hline & \multicolumn{3}{|c|}{ Social effects } & \multirow{2}{*}{ Total } \\
\hline & 1 & 2 & 3 & \\
\hline Demolition effects count \% within social effects & $\begin{array}{c}30 \\
100.0 \%\end{array}$ & $\begin{array}{c}64 \\
100.0 \%\end{array}$ & $\begin{array}{c}96 \\
100.0 \%\end{array}$ & $\begin{array}{c}190 \\
100.0 \%\end{array}$ \\
\hline Total count \% within social effects & $\begin{array}{c}30 \\
100.0 \%\end{array}$ & $\begin{array}{c}64 \\
100.0 \%\end{array}$ & $\begin{array}{c}96 \\
100.0 \%\end{array}$ & $\begin{array}{c}190 \\
100.0 \%\end{array}$ \\
\hline
\end{tabular}

Where: 1—Fail to pay medical bill. 2-Fail to pay school fees. 3-Fail to pay rent hence eviction.

Table 11. Cross tabulating demolition to change of life plans.

\begin{tabular}{|c|c|c|c|c|}
\hline & \multicolumn{3}{|c|}{ Life plan change } & \multirow{2}{*}{ Total } \\
\hline & 1 & 2 & 3 & \\
\hline Demolition effects count \% within life plan change & $\begin{array}{c}153 \\
100.0 \%\end{array}$ & $\begin{array}{c}87 \\
100.0 \%\end{array}$ & $\begin{array}{c}37 \\
100.0 \%\end{array}$ & $\begin{array}{c}277 \\
100.0 \%\end{array}$ \\
\hline Total count \% within life plan change & $\begin{array}{c}153 \\
100.0 \%\end{array}$ & $\begin{array}{c}87 \\
100.0 \%\end{array}$ & $\begin{array}{c}37 \\
100.0 \%\end{array}$ & $\begin{array}{c}277 \\
100.0 \%\end{array}$ \\
\hline
\end{tabular}

Where: 1 -Fail to reach target. 2-Decided to change activity. 3-Decided to migrate to another place.

Table 12. Cross tabulating demolition to marriage impacts.

\begin{tabular}{|c|c|c|c|}
\hline & \multicolumn{2}{|c|}{ Marriage suffers } & \multirow{2}{*}{ Total } \\
\hline & 1 & 2 & \\
\hline Demolition effects count \% within marriage suffers & $\begin{array}{c}69 \\
100.0 \%\end{array}$ & $\begin{array}{c}32 \\
100.0 \%\end{array}$ & $\begin{array}{c}101 \\
100.0 \%\end{array}$ \\
\hline Total count \% within marriage suffers & $\begin{array}{c}69 \\
100.0 \%\end{array}$ & $\begin{array}{c}32 \\
100.0 \%\end{array}$ & $\begin{array}{c}101 \\
100.0 \%\end{array}$ \\
\hline
\end{tabular}

Where numbers (key) stands for: 1-Conflicts in marriage increased. 2-Excessive drinking.

study applied both qualitative and quantitative analytical methods to understand the extent of the impacts of the entire process of road transformation. Both methods demonstrated that people who were conducting socioeconomic activities along the corridor were affected and that the primary impact (demolition of physical space) triggered a number of other impacts such as losing both financial or social capital (secondary impact), which then trickled down to other impacts (tertiary level) such as losing trust from where some had borrowed money, bankruptcy, laying off workers, psychological and emotional disturbances, marriage breakdown, etc. As a result of these, many people who were conducting socio-economic activities along the corridor developed a negative interest to the project.

This is supported by the findings by two scholars whose study affirms that millions of people who are resettled yearly in the name of development and progress they endure social and cultural disruption as well as economic upheaval, and their voices are rarely heard (McDowell, 2012). The same continues to iterate that other people face challenges such as the loss of cultural identity, shifting social roles, and fractured family relation- 


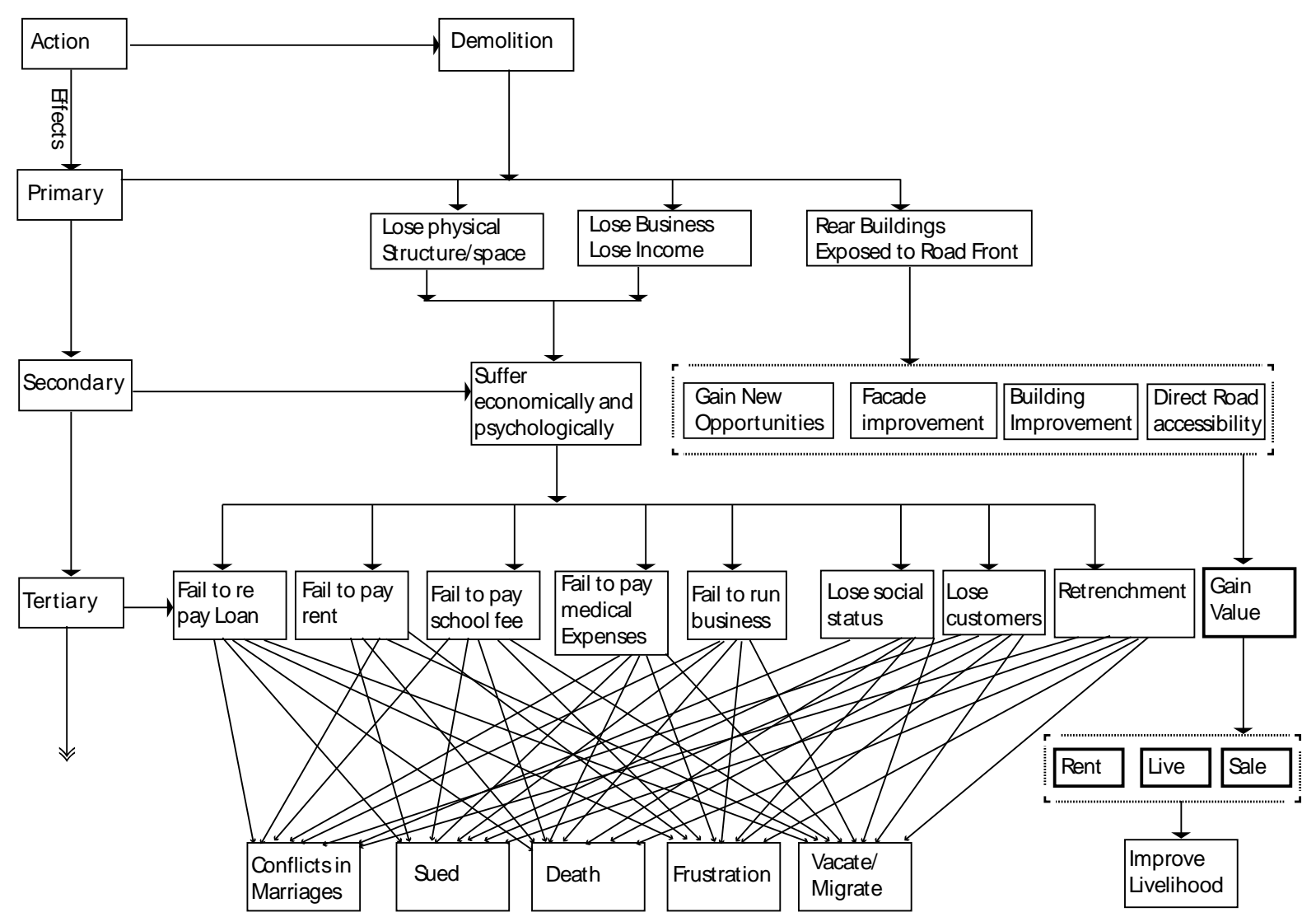

Figure 5. Concatenating impacts as observed in the overall study. Author, 2015.

ships (Ibid).

Analysis has shown that the spatial transformation (demolition of physical space) has a strong connection with the emotion of the people as well as to their social connection to their place of living meaning that whenever a physical space is altered, expectation of social impact is inevitable. This is supported by scholars such as Lefebvre when he concedes that physical space is a product of the society inhabiting it and it can be taken as a complex social construction (based on values, and the social production of meanings) which affects spatial practices and perceptions (Lefebvre, 1991: p. 30).

Although the issue of compensation was not the central point in this study, respondents showed that they were compensated. However, the compensation in terms of hard cash could not solve social issues. In a different study, it has been found that hard cash compensation may be the source of social problems such as landlessness and jobless (Terminski, 2013). The same study continues to unveil that compensation in cash often leads to improper expenditure by individuals who are unaccustomed to large amounts of it or who have followed a landbased economic model not based on money and that the author advises that compensation should not be taken as a one-time process of redressing the loss caused by relocation. This is due to the fact that very often displaced people cannot cope with the new economic situation presented by deportation; the difference between their former economic model and their actual needs is too great. It seems important, therefore, to ensure long-term economic support mechanisms such as new jobs or educational prospects to cope with the displacement. In many cases, social support mechanisms are the only means of preventing the potential multigenerational exclusion brought about by involuntary resettlement. In the case of Morogoro road, it was revealed that although people were compensated, yet, at the end they complained of failure to pay house rent, paying school fees, failing to meet their target and some had their marriages broken.

The government's intension to transform the Morogoro road to accommodate BRT system is a brilliant idea to ease many years congestion in the city, however, according to this study and at individual family and community level, the project has tremendous effects on the socioeconomic activities that are used to support livelihood in the surrounding. The study revealed some of the direct impacts such as retrenchment for workers sup- 
porting in sales, inaccessibility by trucks as in the previous situation and, disruption of utilities. Moreover, activities such as sale of clothes, building materials, groceries, saw mills, etc. were removed.

According to the framework, the study shows that the effects of demolition should not be under-estimated or limited to the spatial level alone. It is supposed to be thoroughly studied and considered whenever the government wants to displace people for development-related projects. The framework shows that the effects continue indefinitely, however, after tertiary level neither consultants nor government gives attention to what transpires to the displaced people. In this framework, the tertiary level impacts of demolition are silently affecting the victims of displacement to the level of marriage conflicts, children dropping from school, eviction and frustrations. People to be displaced need to be educated to be aware of the likely impacts they may face after compensation for demolition and that the government or established social agents should continue to monitor the lives of the people affected by demolition.

\section{References}

Ahrentzen, S. B. (1992). Home as Workplace in the Lives of Women. In I. Altman, \& S. M. Low (Eds.), Place Attachment: Human Behavior and Environment (pp. 113-138). New York, NY: Plenum Press.

http://dx.doi.org/10.1007/978-1-4684-8753-4_6

Allen, D. (2005). MBTA Silver Line. www.nycsubway.org

Bentley et al. (1985). Responsive Environment, a Manual for Designers (pp. 85-95). Oxford: Butterworth Architecture.

Cernea, M. M. (1996). Public Policy Responses to Development-Induced Population Displacement. Economic and Political Weekly, 31, 1515-1523.

Finnigwa, S. (2013). Bitter Side of Dar es Salaam Milestone Project. Tanzania Daily News 24 Tanzania Report.

Gilgun, J. (1994). A Case for Case Studies in Social Work Research. Social Work, Academic Journal, 39.

Ghauri, P., \& Gronhaug, K. (2002). Business Research Methods in Business Studies: A Practical Guide (2nd ed.). Sydney: Prentice Hall.

Harvey, D. (1996). Justice, Nature and the Geography of Difference, Cambridge: Blackwell Publishes.

Heidegger, M. (1958). An Ontological Consideration of Place (J. T. Wilde \& W. Kluback, Trans.). In M. Heidegger (Ed.), The Question of Being (pp. 18-27). New York: Twayne Publishers.

Comey, J. (2004). An Improved Living Environment? Housing Quality Outcomes for HOPE VI Relocatees, (Policy Briefs/Metropolitan Housing and Communities: A Roof over their Heads). Minneapolis: Urban Institute.

Lefebvre, H. (1991). The Production of Space. London: Basil Black Well.

Wen, L. W., Hodgetts, D., \& Ho, E. (2010). Gardens, Transition and Identity Reconstruction among Older Chinese Immigrants to New Zealand. Journal of Health Psychology, 15, 786-796. http://dx.doi.org/10.1177/1359105310368179

Li, W. W., \& Chong, M. D. (2012). Transnationalism, Social Wellbeing and Older Chinese Migrants. Graduate Journal of Asian and Pacific Studies, 8, 29-44.

Manzo, L. C. (2005). For Better or Worse: Exploring Multiple Dimensions of Place Meaning. Journal of Environmental Psychology, 25, 67-86. http://dx.doi.org/10.1016/j.jenvp.2005.01.002

Cunningham, M. K. (2004). An Improved Living Environment? Relocation Outcomes for HOPE VI Relocatees (Policy Briefs/Metropolitan Housing and Communities: A Roof over Their Heads). Minneapolis: Urban Institute, Brief No. 1, 1-7. http://www.urban.org/UploadedPDF/311057 Roof 1.pdf

McDowell, C. (1996). Understanding Impoverishment: The Consequences of Development-Induced Displacement. Oxford: Berghahn.

Bennett, O., \& McDowell, C. (2012). Displaced: The Human Cost of Development and Resettlement. New York: Palgrave Macmillan (Inbunden), 1-10. http://dx.doi.org/10.1057/9781137074232

OP-710 (1988). Inter-American Development Bank. Guideline for Resettlement Plans. http://www.iadb.org/pri/PDFs/B ResettlePlan.pdf

Lai, P. (2007). China Planning Network 1st Urban Transportation Congress Beijing, China. Integration of Land Use and Transportation Development around Transit Systems, Beijing, 2-4 August 2007.

Satg'e, A. (2002). Learning about Livelihoods: Insights from Southern Africa. Oxfam Publishing.

Schramm, W. (1971). The Process and Effects of Mass Communication (Rev. ed.). Urbana, IL: University of Illinois Press.

Terminski, B. (2013). Development-Induced Displacement and Resettlement: Theoretical Frameworks and Current Challenges. Geneva. 
http://dlc.dlib.indiana.edu/dlc/bitstream/handle/10535/8833/Bogumil\%20Terminski\%2c\%20development-Induced\%20Displace ment\%20and\%20Resettlement.\%20\%20Theoretical\%20frameworks\%20\%20and\%20current\%20challenges.pdf?sequence $=1$

Yin, R. (2002). Case Study Research: Design and Methods (3rd ed.). Applied Social Research Methods Series, Volume 5, London: Sage Publications Ltd.

Submit or recommend next manuscript to SCIRP and we will provide best service for you:

Accepting pre-submission inquiries through Email, Facebook, Linkedin, Twitter, etc A wide selection of journals (inclusive of 9 subjects, more than 200 journals)

Providing a 24-hour high-quality service

User-friendly online submission system

Fair and swift peer-review system

Efficient typesetting and proofreading procedure

Display of the result of downloads and visits, as well as the number of cited articles

Maximum dissemination of your research work

Submit your manuscript at: http://papersubmission.scirp.org/ 